\title{
Turismo em favelas: notas etnográficas sobre um debate em curso
}

\author{
Favela Tourism: ethnographic notes on an ongoing debate
}

\section{Camila Moraes ${ }^{\mathrm{a}}$}

\begin{abstract}
Resumo As favelas do Rio de Janeiro têm sido alvo de intensa visitação turística desde os anos 2000. Se antes esse turismo se concentrava na Rocinha, paradigmática favela turística, hoje expande-se para outras favelas da cidade, e tal expansão vem acompanhada da ampliação do debate sobre esse tipo específico de turismo. Neste artigo, analiso três eventos de disputa em torno do tema "turismo em favelas", ocorridos entre 2014 e 2015: a série de debates "Fala Vidigal!"; o I Congresso de Turismo de Base Comunitária da Rocinha; e o Grupo de Trabalho (GT) sobre Turismo em Favelas na Câmara dos Vereadores do Rio de Janeiro. Os três eventos se apresentaram como interessantes cenários para observação participante e análise dos discursos sobre turismo em favela, tanto por parte da academia, como também por parte de empreendedores externos, empreendedores locais, moradores de favelas e órgãos públicos.
\end{abstract}

Palavras-chave Turismo; Favelas; Discursos; Rio de Janeiro

Abstract Favelas of Rio de Janeiro have been intensely visited by tourists since the 20oos. If at first, favela tourism was concentrated in Rocinha, the paradigmatic tourist favela, today it expands to other favelas of the city, and this expansion is followed by a broadening debate about this type of tourism. I examine three events that occurred between 2014 and 2015, and where the meanings of this type of tourism are disputed: the series of debates "Speak up Vidigal!"; the I Congress of Community Tourism in Rocinha; the Favela Tourism Working Group in the City Council of Rio de Janeiro. These three events present themselves as an interesting setting for participant observation and discourse analysis on favela tourism by the academy, as well as by foreign entrepreneurs, local entrepreneurs, favela residents and public agencies. Keywords Tourism; Favela; Discourse; Rio de Janeiro.

a Professora Assistente do Departamento de Turismo e Patrimônio (UNIRIO), doutoranda do Programa de Pós-Graduação em História, Política e Bens Culturais (CPDOC/FGV-RJ) e coordenadora do Observatório do Turismo em Favelas (UNIRIO). 


\section{INTRODUÇÃO}

Em alguns lugares vocês vão ouvir chamar de favela; outros, de morro; em outros, comunidade; em outros lugares vai ser complexo; mas em todos os lugares o morador é o protagonista de tudo que a gente está falando (Fala de guia local no I Congresso de Turismo de Base Comunitária da Rocinha, 2015).

Na virada do milênio assistimos ao surgimento de um novo atrativo turístico na cidade do Rio de Janeiro: as favelas. De acordo com Freire-Medeiros (2009, 2013), as visitas às favelas do Rio de Janeiro não são exatamente uma novidade, pois existem registros de viajantes circulando nessas áreas desde os anos 1940. No entanto, o fenômeno analisado pela pesquisadora nos anos 2000 se refere à transformação da favela em marca e mercadoria, através do fenômeno por ela denominado travelling favela (favela viajante), que ilustra como a favela viaja através de imagens e objetos que se autodenominam como representativos ou oriundos da própria favela.

Nesse contexto, as favelas passam a ser consideradas como marca e mercadoria, de modo que algumas delas foram transformadas em atração turística e incorporadas entre as coisas para ver no Rio de Janeiro, seja por iniciativas internas e / ou externas. No que diz respeito ao caso do Rio de Janeiro, é possível identificar um papel fundamental das políticas públicas na mobilização turística das favelas e na expansão do turismo nessas áreas entre 2009 e 2016. Nas favelas mais visitadas, as políticas públicas têm promovido e apoiado a expansão para fins de desenvolvimento social e vêm sendo apresentadas também como um resultado de novos projetos de segurança pública (FrENZEL ET AL., 2015). Se até 2008 a Rocinha era a principal favela turística, a partir de 2009 ela começa a compartilhar a atenção dos turistas com Santa Marta, Complexo do Alemão e Vidigal, entre outras, principalmente por causa das políticas públicas implementadas nessas áreas.

É importante notar ainda que, a partir de 2009, o Rio de Janeiro se torna uma "cidade-sede" de megaeventos como a Copa do Mundo da FIFA de 2014 e os Jogos Olímpicos de 2016. Para Soares Gonçalves (2013), nesse contexto de megaeventos, a inserção das favelas na cidade parece estar "mais do que nunca condicionada às suas novas configurações de áreas pacificadas, patrimonializadas para o turismo" (SoAREs GonçAlves, 2013, p.33). E nesta conjuntura, espaços de reflexão e debates sobre turismo ganham destaque em favelas da cidade: a série de debates Fala Vidigal!; o I Congresso de Turismo de Base Comunitária da Rocinha; e o Grupo de 
Trabalho sobre Turismo em Favelas, realizado na Câmara dos Vereadores. Os três momentos selecionados ocorreram como resultado da expansão do turismo em favelas no contexto dos megaeventos na cidade. $\mathrm{O}$ Fala Vidigal! ocorreu às vésperas da Copa do Mundo. O Congresso da Rocinha e o Grupo de Trabalho, por sua vez, ocorreram em 2015, período entre a Copa do Mundo e os Jogos Olímpicos, sendo assim bastante propício para reflexões sobre 2014 e as preparações para 2016.

Neste sentido, busco analisar aqui a resposta dos moradores a essa movimentação das favelas em direção ao sistema turístico internacional. Pois, assim como Freire-Medeiros (2009) já identificava em sua pesquisa, os moradores não estão alheios a este processo, e suas opiniões sobre o turismo em favelas não são exatamente polarizadas entre contrários ou favoráveis, correspondendo antes a um contínuo, com várias gradações possíveis, que varia de acordo com as relações ou encontros turísticos performados nas diversas favelas. Deste modo, o que analiso neste artigo é a apropriação pelos moradores da linguagem dominante nos assuntos sobre turismo, especialmente entre pesquisadores e Estado, em resposta à elaboração ou reelaboração das favelas turísticas no contexto dos megaeventos na cidade do Rio de Janeiro.

Para isso, este artigo foi elaborado com base em observação participante realizada nos debates apontados. A observação se deu durante pesquisa de doutorado, quando estreitei laços com moradores de favelas atuantes no turismo, além de contato travado com outros pesquisadores e profissionais da área. Foi através dessas redes que cheguei aos debates aqui analisados, sendo ainda convidada para palestrar em um deles, como será visto mais à frente.

Diante do exposto, este artigo prossegue organizado em três seções, cada uma delas dedicada à apresentação e ao exame de cada um dos eventos citados. Por fim, concluo que o turismo em favelas passou a ser percebido como importante fenômeno sociopolítico, investigado e interpretado por diversos setores da sociedade, em especial pelos moradores das próprias favelas, interessados em pensar, elaborar e se apropriar de linguagens, compreender as extensões, os limites e o futuro deste fenômeno.

\section{“FALA VIDIGAL!”: TURISMO E GENTRIFICAÇÃO EM DEBATE}

Considerando que cada favela é uma favela, cada experiência de turismo em favela terá suas características e peculiaridades. O Vidigal está localizado na Zona Sul do Rio de Janeiro, entre os bairros Leblon e São Conrado e sobre o Morro Dois Irmãos. Exemplo de luta contra o histórico processo de remoções ocorrido nos anos 70 (Soares Gonçalves, 2013; MacCann, 2014), o Vidigal também é reconhe- 
cido pela sua classe artística de pintores, escultores, atores e cantores, que habita as casas e apartamentos na parte baixa do morro (CoutinHo, 2006). Ao chegar ao Vidigal, o visitante se depara com prédios e casarões, e subindo a encosta, avista a favela. Assim como outras áreas do Rio, teve períodos marcados pela violência e pelo tráfico de drogas. Em janeiro de 2012, o Vidigal recebeu uma Unidade de Polícia Pacificadora (UPP), o que é, segundo alguns grupos de moradores, umas das razões para o crescimento do turismo no local.

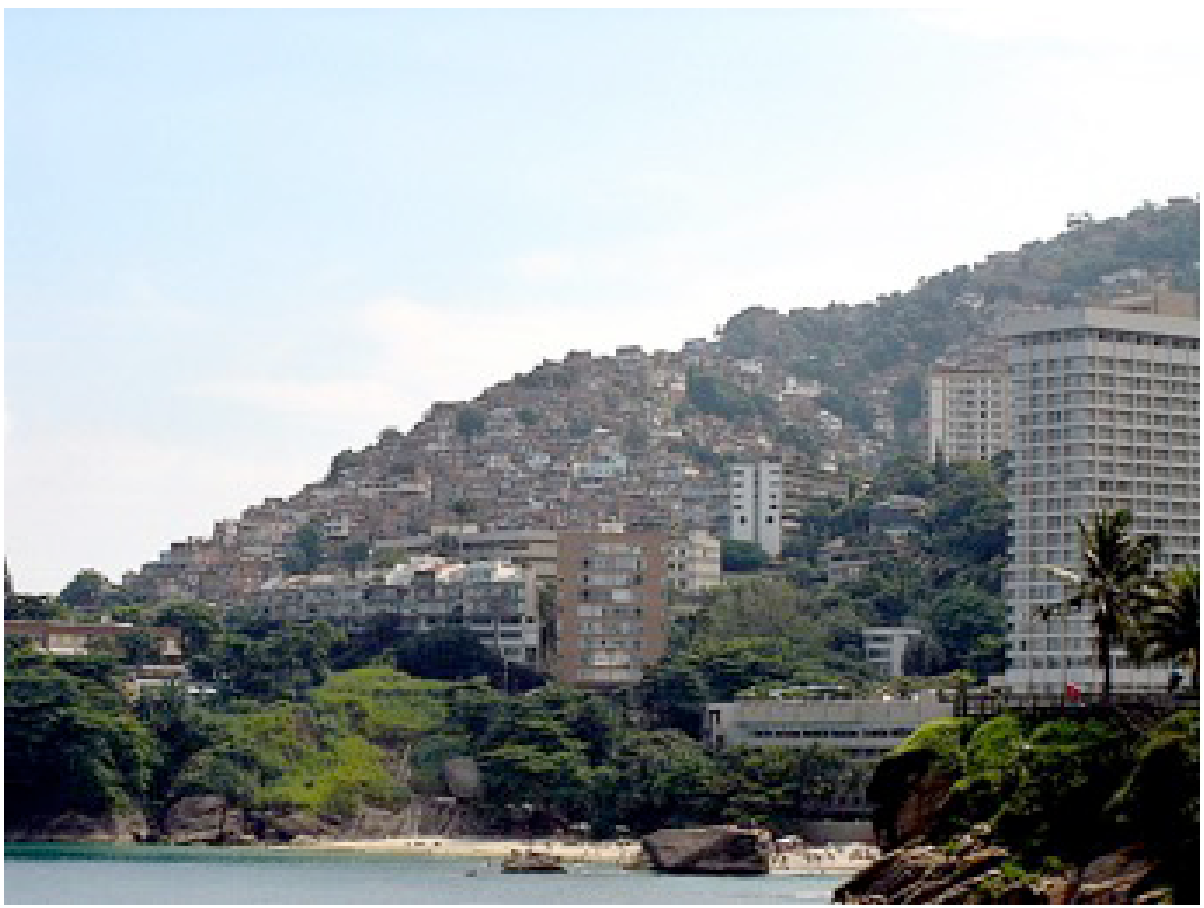

Figura 1. Vidigal. Fonte: Foto de Jeff Belmonte.

Disponível em: https://commons. wikimedia.org/w/index.php?curid=44010

O turismo no Vidigal se caracteriza pela rápida expansão interna, com a abertura de inúmeros albergues, bares e restaurantes, a "descoberta" da Trilha do Morro Dois Irmãos pelos turistas, bem como por sua entrada no circuito da noite carioca, sendo eleito local favorito para as mais recentes festas da moda na cidade. Merece destaque ainda o fato de o Vidigal não ter sido "descoberto" e/ ou "invadido" apenas por turistas: a circulação dos moradores de outras áreas da

1 Chamo aqui de "descoberta", pois se trata na verdade de um caminho utilizado por trabalhadores que atuam no Programa Mutirão de Reflorestamento da Prefeitura do Rio de Janeiro realizado na região de mata no entorno do Vidigal, desde os anos 1980. Com a implantação da UPP, turistas e visitantes passaram a frequentar esta que se tornou uma das principias trilhas do Rio de Janeiro em 2014, e está contemplada entre os roteiros indicados para os Jogos Olímpicos Rio 2016. Ver: https://www.rio2016.com/noticias/que-tal-uma-trilha-no-vidigal-passaporte-verde-leva-turistas-a-comunidade. Acesso em: 19 de outubro de 2016. 
cidade nos bares, restaurantes, festas e trilha são bem frequentes, podendo ainda superar em alguns momentos a presença de turistas estrangeiros.

Todos esses fluxos de pessoas e capitais, com novos investidores e novos negócios sendo abertos, mobilizaram o Fórum Intersetorial do Vidigal, que reúne pessoas e organizações ligadas a trabalhos sociais e prestação de serviços nessa favela. Nesse contexto, o Albergue da Comunidade, que reúne moradores interessados em alugar quartos ou casas para turistas; a ONG Comunidades Catalisadoras, que reúne pesquisadores e busca o empoderamento e a comunicação através de um centro de estudos sobre favelas; e a Associação de Moradores organizaram, entre março e junho de 2014, a série de debates Fala Vidigal!.

Os debates aconteceram às terças-feiras à noite na praça e no anfiteatro na entrada do Vidigal, que é um local de passagem para os moradores. Os debates foram filmados e relatados pela equipe da ONG Comunidades Catalisadoras e os conteúdos foram disponibilizados na internet ${ }^{2}$. Os debates contaram com um impressionante público de fotógrafos, jornalistas, pesquisadores e moradores, que variaram entre cerca de 120 e 250 pessoas a cada noite.

No dia 18 de março de 2014, ocorreu o primeiro debate dedicado à "Especulação Imobiliária e o aumento dos preços no Vidigal”. Na mesa, lideranças comunitárias, moradores, pesquisadores e empreendedores locais falaram sobre o surgimento das favelas como alternativa de habitação na cidade; o histórico de lutas do Vidigal contra as remoções; apresentaram o fenômeno global da gentrificação, como esta aparece na mídia muitas vezes colocada como benéfica e traduzida como revitalização; e os movimentos de resistência pelo mundo, a exemplo do Occupy Wall Street ${ }^{3}$.

Esse primeiro debate tinha como objetivo, portanto, apresentar o que é a gentrificação. Fenômeno largamente debatido e teorizado na academia, identificado pela primeira vez nos anos 1960 na Rua Glass, em Londres, quando a expressão gentrification foi utilizada em comparação a um hábito próprio da gentry, a classe média-alta inglesa das áreas rurais que, além de sua residência no campo, mantinha uma residência na cidade. As primeiras descrições que utilizaram o termo gentrification destacavam, fundamentalmente, a revalorização experimentada por uma classe-média alta britânica em alguns bairros da capital. Van Weesep (1994) resume

2 Ver: http://rioonwatch.org.br/?s=fala+vidigal. Acesso em: 19 de outubro de 2016.

3 O movimento global dos "ocupas", como o Occupy Wall Street, se caracterizou pelos acampamentos de estudantes e trabalhadores em áreas públicas em cidade de todo o mundo. Iniciado no segundo semestre de 2011, teve como uma de suas principais bandeiras a crítica à desigualdade econômica (PESCHANSKI, 2012). 
a gentrificação como "uma expressão espacial de uma profunda mudança social” e destaca que a maioria das descrições e análises publicadas ao longo dos anos mostra como a gentrificação é um processo diversificado que pode transformar total ou parcialmente uma área; é protagonizado por uma série de agentes e suas causas e efeitos são complexos e difíceis de determinar (VAN WEESEP, 1994).

Nos anos 1970, a gentrificação passa a ser um fenômeno comum nos países industrializados ao longo da chamada era pós-industrial, com o declínio do modelo socioeconômico industrial tradicional. Caracteriza-se, em geral, pela ocupação dos centros das cidades por uma parcela da classe média, provocando a saída dos habitantes da classe baixa, que viviam no local (BATALLER, 2012). Nesse sentido, o fenômeno percebido por alguns pesquisadores e moradores no Vidigal se assemelharia à gentrificação. Isto porque, para estes, a saída de antigos moradores para a entrada dos novos moradores de classe média ou estrangeiros, que chegam à favela fazendo "boas" propostas de compra dos imóveis locais, seria um "sintoma do processo de gentrificação". Este cenário provoca uma reflexão acerca do futuro do Vidigal, em especial, se essas mudanças e movimentos seriam de fato capazes de transformar ou até acabar com a favela. Por um lado, em diversos momentos, ouvi de moradores do Vidigal e de outras favelas referências à "remoção branca" como um sinônimo da gentrificação ou, em última análise, o resultado final deste processo que culminaria numa silenciosa remoção da favela. Por outro lado, há também moradores que consideram que este movimento de saída e entrada de antigos e novos moradores sempre ocorreu, e que esse momento de expressiva compra e ocupação de imóveis por classe média ou estrangeiros já não é mais crescente e tão assustador.

Após o primeiro debate, houve mais três encontros. O segundo ocorreu no dia 8 de abril de 2014 e abordou o tema “Que Vidigal você quer no futuro?”. Os organizadores exibiram um vídeo ${ }^{4}$ com depoimentos de moradores sobre o Vidigal e as recentes mudanças, além do depoimento de um estrangeiro, um dos novos moradores, e do fundador do Grupo de Teatro Nós do Morro 5 .

No dia 6 de maio de 2014, o terceiro debate abordou o tema "Os novos empreendedores: o que os novos empresários pretendem para a comunidade?”. Nessa noite, a mesa foi composta por um representante do Albergue Mirante do Arvrão

4 Ver: https://www.youtube.com/watch?v=bdlrpTsIllE. Acesso em: 19 de outubro de 2016.

5 Guti Fraga, Fred Pinheiro, Fernando Mello da Costa e Luiz Paulo Corrêa e Castro, protagonizaram a história do Nós do Morro, que começa a partir da amizade entre os quatro e da interação com as pessoas da favela nos bares locais. As peças do grupo teatral abordam a história e o dia-a-dia da favela (CoutinHo, 2006). 
e um representante da Escola de Arte e Tecnologia, projeto social do artista plástico Vik Muniz. Segundo a organização do debate, outros novos empreendedores foram convidados, mas somente os dois citados confirmaram presença e compareceram. Na mesa, os dois representantes compartilharam a preocupação de seus estabelecimentos não estarem sendo plenamente bem-vindos na comunidade e se disponibilizaram a participar do debate para esclarecer quaisquer dúvidas. Ambos, o albergue e o projeto social, têm suas sedes no Arvrão, parte alta do Vidigal, de onde tem-se as melhores vistas da favela e da cidade, e também por onde se acessa a badalada trilha do Morro dos Irmãos. O local é o cenário das principais mudanças no morro, provocadas pela abertura de novos albergues, bares e quiosques, que vem alterando a paisagem da parte alta do Vidigal. As duas iniciativas tiveram grande repercussão dentro e fora da favela. O albergue chama a atenção por ser considerado uma hospedagem luxuosa em meio à favela, com quartos que não deixam a desejar se comparados aos melhores hotéis da cidade. E o projeto social do artista plástico promete muita inovação com uso de um método experimental de educação, que combina arte e tecnologia, desenvolvido pelo Massachusetts Institute of Technology (MIT), respeitada instituição americana de ensino e pesquisa na área tecnológica.

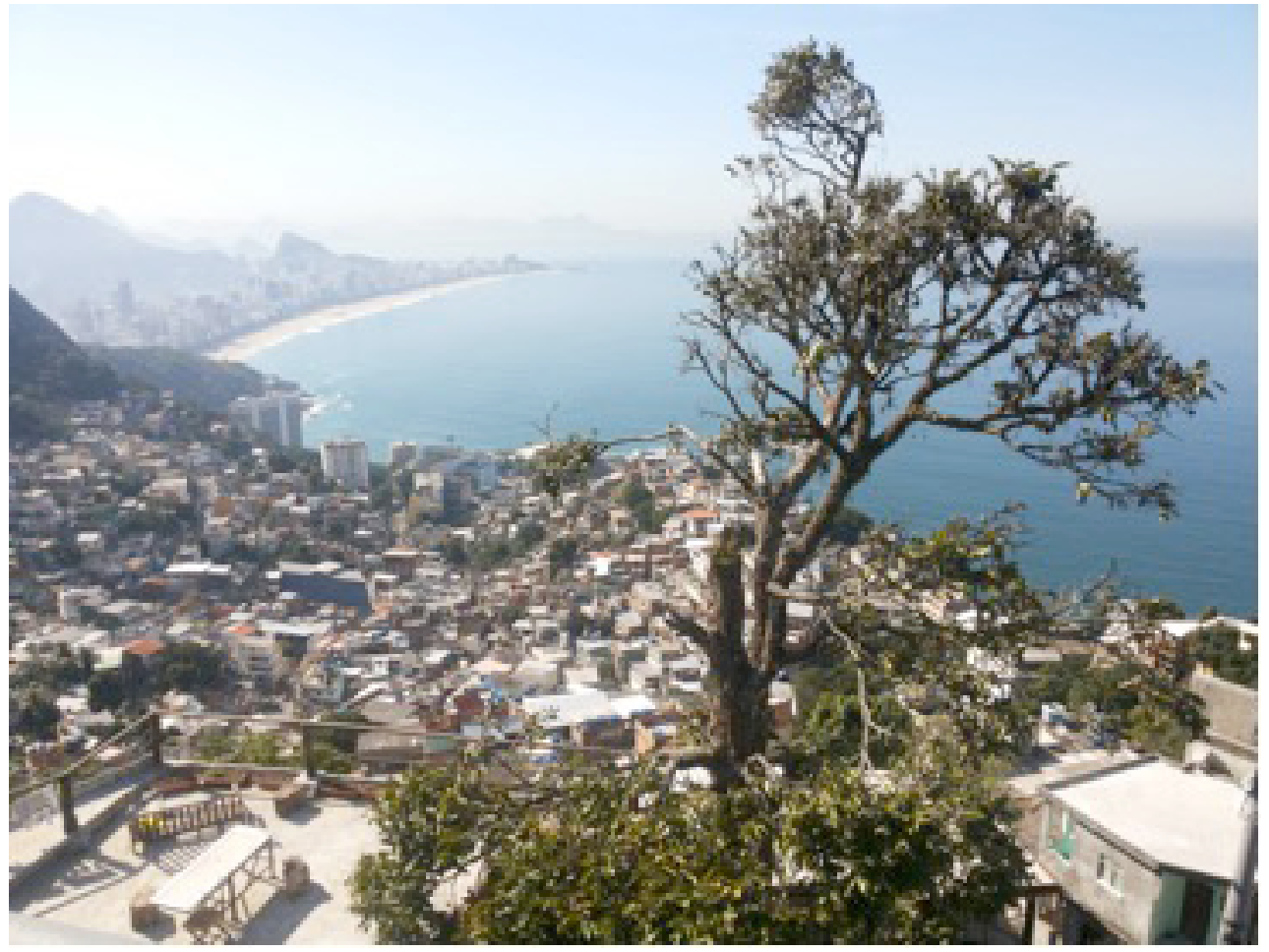

Figura 2. A árvore símbolo do Arvrão com o Vidigal e a cidade ao fundo. Fonte: Foto da autora. 
No dia 3 de junho de 2014, aconteceu o quarto e último encontro intitulado “O poder público tem a palavra: o que o poder público pretende para o Vidigal?”. Estavam presentes um representante da Unidade de Polícia Pacificadora (UPP), que se apresentou como "um programa que visa garantir o direito de vida dos cidadãos em colaboração com a comunidade local”, no Vidigal desde 2012; a UPP Social, que se apresentou como um "programa que tem o objetivo de através do diálogo integrar áreas da cidade que historicamente estavam apartadas pela violência"; o Posto de Orientação Urbanístico e Social (POUSO), dedicado ao planejamento, licenciamento e fiscalização das construções na cidade; a Light, que vem atuando nas favelas com renovação da rede e instalação de novos medidores; e a Guarda Municipal, que explicou sua atuação no ordenamento público e sinalização das vias conforme requisitado pela comunidade.

A novidade trazida por estes debates no Vidigal foi reunir lideranças locais, pesquisadores, os novos empreendedores da favela, o poder público e os moradores com o objetivo de discutir a gentrificação no Vidigal, como esta vem sendo percebida pelos moradores e as formas para se contornar ou resistir a este processo. E não apenas: ao longo dos debates, representantes de movimentos sociais, representantes de outras favelas e ONGs se colocaram sobre o tema da gentrificação em outras favelas. Um morador da Babilônia e representante do grupo Favela Não se Cala $^{6}$ falou sobre como o mesmo processo se dava em sua favela, e o relacionou ao "turismo de realidade", forma como o turismo em favela muitas vezes é tratado (Jaguaribe e Hetherington, 2004; Freire-Medeiros, 2007). Assim como o Vidigal, a Babilônia é outra favela da Zona Sul do Rio de Janeiro, localizada no bairro do Leme próximo a Copacabana, centro turístico da cidade. Nesta favela proliferam hospedagens, assim como são também comuns os roteiros que levam turistas para o Parque Natural Municipal da Paisagem Carioca acessado pela parte alta da favela com trilhas e belos mirantes.

Durante a fala do morador da Babilônia, manifestações contrárias ao turismo faziam eco na plateia e pessoas gritavam palavras de ordem, como por exemplo, “aqui não é zoológico!", fazendo referência à expressão "safari de pobres" utilizada pelas mídias e setores da classe média nas criticas ao turismo em favelas no Rio de Janeiro (Freire-Medeiros, 2009). Para concluir sua fala sobre turismo e gentrificação, o morador fez uma crítica às recentes políticas públicas na favela e chamou a atenção para o caso do Teleférico do Alemão. Parte das obras do Programa de

6 Movimento que busca articular favelas, baixadas e periferias do Brasil para enfrentar os desafios comuns da atual conjuntura do sistema. 
Acelerção do Crescimento (PAC) no Complexo de favelas do Alemão, Zona Norte do Rio de Janeiro, a impressionante obra de mobilidade e urbanismo é muitas vezes criticada pelos moradores do complexo de favelas, que não percebem a real utilidade do teleférico para o morador, mas sim para o turista, que tem a possibilidade de sobrevoar as favelas do complexo sem sair das gôndolas do teférico, sendo apelidado de obra pra "gringo ver", ou seja, uma política pública de melhoria da favela para turistas e visitantes e não necessariamente para o morador.

Presente em todos os debates, a representante da Organização Mulheres do Vidigal sempre relatava algumas situações que vinham acontecendo na favela em que o morador se sente prejudicado em detrimento de pessoas identificadas como "de fora" ou "do asfalto". Primeiro, ela citou o exemplo de algumas mulheres do Vidigal à procura de empregos em hotéis e albergues do morro, e explicou que os homens ainda conseguem emprego na favela nas obras, mas as mulheres dificilmente têm empregos nos albergues e nos hotéis. Segundo a ativista, os donos dos empreendimentos dizem que "elas não têm experiências para atuar no hotel, a não ser na limpeza". A jovem argumentou ainda que hoje no Vidigal "tem emprego para gente de fora da favela na favela, mas não tem emprego para quem é da favela na favela, assim como não tem mais lazer para quem é da favela, na favela”.

Esse foi outro ponto recorrente nos debates: para os moradores, suas festas são hoje proibidas, não há mais baile funk, nem roda de samba, apenas as festas dos albergues, que são voltadas para os turistas e para uma classe média alta carioca. A falta de lazer para moradores se apresenta como parte da gentrificação, que seria agravada com as compras de casas nas favelas, para instalação de novos projetos e abertura de novos albergues, bares e restaurantes. Para os moradores "cada casa vendida no Vidigal é uma ou duas famílias a menos de nascidos e criados no morro".

A presença de estrangeiros e da classe média como "novos moradores" ou "novos empreendedores" do Vidigal apareceu frequentemente nos debates, mas dividiu a plateia. Para alguns, os estrangeiros muitas vezes vistos como os responsáveis pela gentrificação, são muito bem vindos na favela e sempre foram desde os anos 1970 e 1980, indicando que tal presença não é exatamente uma novidade, mas que antes não se falava em gentrificação. Para outros, não são apenas os estrangeiros que provocam a gentrificação, mas também pessoas de classe média que não conseguem mais bancar os altos preços em bairros da zona sul do Rio de Janeiro.

O tema da habitação foi revisitado em todas as noites do Fala Vidigal. Em um dos debates, um representante da Associação de Moradores fez um apelo aos moradores para pensarem antes de venderem as casas, que parecem valer muito, mas com o mesmo dinheiro, às vezes não compram outra casa no Vidigal e nem 
mesmo perto, e como consequência, terão que mudar seu modo de vida e seus hábitos, indo para uma outra área da cidade, ou até mesmo fora da cidade. Muitos moradores especulam que a venda de casas na parte alta do Vidigal é um sinal de que aquela área vai virar um condomínio, ou seja, uma área à parte da favela, um "condomínio fechado".

Os moradores questionaram muitas vezes o crescimento desordenado e a atuação da prefeitura que "não faz valer a lei”, ou melhor, que, na prática, "o que vale para uns não vale para outros", referindo-se em especial às novas construções na favela. Para os antigos moradores, os novos residentes ou empreendedores da favela conseguem construir rápido e sem impedimentos, enquanto que as obras e construções dos antigos são sempre taxadas como irregulares ou em áreas de risco.

Outro importante aspecto nos debates foram as recentes políticas públicas nas favelas, em especial a UPP. Para os moradores, a UPP foi apresentada pelo Governo do Estado como uma solução de segurança pública e etapa inaugural de uma nova vida nas favelas com "novos programas sociais", "tranquilidade e segurança", "sem o domínio do tráfico de drogas". No entanto, o que encontraram, nas palavras de lideranças comunitárias foram: "policiais malformados, sem preparação psicológica, sem preparação física e com salários baixos e os moradores continuam aguardando o governo, que nunca aparece”.

O último debate foi encerrado com uma fala que reforçou que as recentes políticas públicas no Vidigal são percebidas como uma das causas da gentrificação, pois preparariam terreno para a entrada da classe média ou dos estrangeiros na favela. Neste sentido, a percepção dos moradores está em consonância com a literatura: segundo Bataller (2012), a movimentação de pessoas é uma das causas da gentrificação, pois vem acompanhada por investimentos e melhorias nas habitações e em seu entorno, incrementando muitas vezes a oferta de equipamentos e serviços. Tais melhorias agregam valor a estas áreas e seus imóveis. "Em conjunto, o fenômeno proporciona uma maior estima das áreas renovadas e, inclusive, uma recuperação do valor simbólico dos centros urbanos" (BATALLER, 2012, p.10).

Em resumo, os debates no Vidigal partiram do tema gentrificação e abordaram uma série de questões recentes na favela. Nos debates foram ouvidos moradores, pesquisadores, representantes de ONGs, os novos empreendedores e, por último, o poder público. A fala sobre o processo de gentrificação, que se inicia no discurso acadêmico, é apropriada e ganha respaldo nas falas dos moradores, que percebem como causa ou efeito da gentrificação o processo de "turistificação" das favelas que, de acordo com Vasconcelos (2005), consiste no reordenamento ou na readequação espacial em função do interesse turístico, sendo o resultado de uma interação 
entre territórios, fluxos de capitais e pessoas que influencia as diferentes esferas da organização socioespacial. Nesse sentido, ambos os processos - gentrificação e turistificação - geram como consequências na favela problemas como os novos empreendimentos que não empregam os moradores, as festas que os excluem, enquanto que as tradicionais festas da favela, como bailes funk e sambas, encontram uma série de barreiras para as suas organizações.

\section{CONGRESSO DE TURISMO DE BASE COMUNITÁRIA DA ROCINHA}

A Rocinha é a paradigmática favela turística do Rio de Janeiro. Vendida no mercado turístico como "a maior favela da América Latina”, está localizada, assim como o Vidigal, entre Leblon e São Conrado, os bairros mais caros da cidade. Vem atraindo grande número de turistas, na sua maioria estrangeiros, nos mais diversos roteiros organizados por diferentes atores, desde 1992. Tal fenômeno tem despertado o interesse de pesquisadores e moradores, bem como do Estado, que em 2006 reconheceu a Rocinha como atrativo turístico oficial da cidade através de projeto de lei de autoria da Vereadora Lilian Sá (Freire-Medeiros, 2009, 2013).

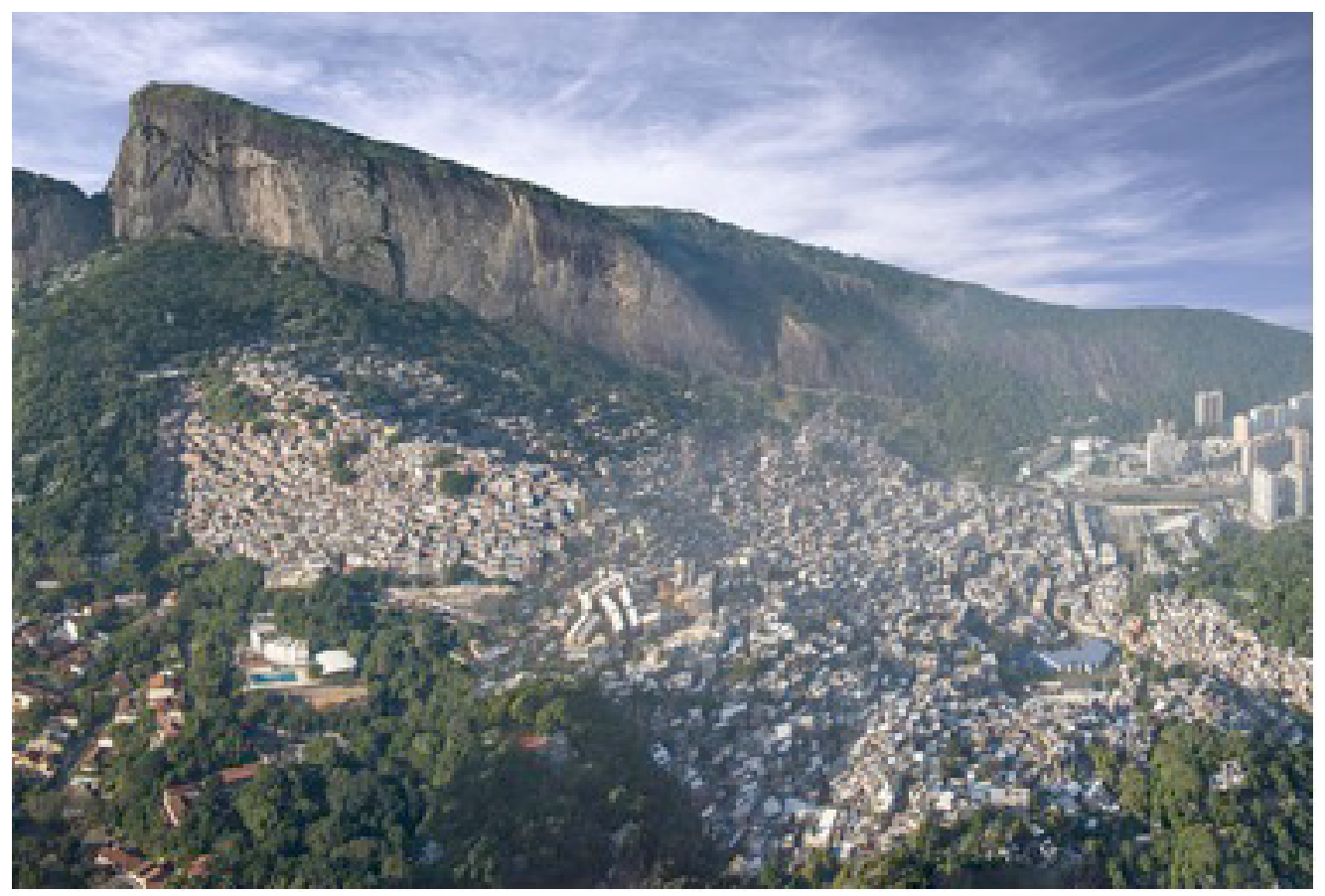

Figura 3. Rocinha. Fonte: Foto de Chensiyuan.

Disponível em: https://commons.wikimedia.org/w/index.php?curid=34324347

Freire-Medeiros chama a atenção para as posições assimétricas ocupadas pelos atores sociais envolvidos no turismo na Rocinha e aponta que o turismo em favela ainda é um segmento que envolve poucos moradores e de forma muito espe- 
cifica, sem efetiva distribuição de lucros, e com pouco diálogo com as instituições representativas da localidade (FreIre-MedeIros, 2009; 2013).

[...] o fato é que os passeios não oferecem à Rocinha a chance de usufruir em pé de igualdade os benefícios econômicos gerados com o turismo. Os turistas gastam pouco durante a visita e, como não há nenhum tipo de distribuição de lucros, os capitais suscitados pelo turismo são reinvestidos apenas minoritariamente na favela e sempre pela via da caridade (FreIRE-MEDEIRos, 2009, p. 77).

São essas assimetrias encontradas na Rocinha que motivaram e mobilizaram a organização do I Congresso de Turismo de Base Comunitária na Rocinha. Resultado de uma pareceria entre o Fórum de Turismo da Rocinha, organização para debate sobre o turismo no local; Programa Rio + Social, programa da Prefeitura do Rio de Janeiro que visa contribuir para o desenvolvimento de políticas públicas de amparo social de favelas que receberam uma Unidade de Polícia Pacificadora (UPP); e o Serviço Brasileiro de Apoio às Micro e Pequenas Empresas (Sebrae), que também atua nas favelas com UPP auxiliando na implantação de novos negócios na favela ou na regularização e melhoria de negócios já existentes. Neste congresso, esses três atores se uniram com o objetivo de discutir o turismo em favelas e aproximar pesquisadores, profissionais do setor, empreendedores, estudantes e gestores públicos. O evento se deu entre os dias 14 e 15 de abril de 2015 na Biblioteca Parque da Rocinha e contou com 135 participantes.

A escolha pela temática “Turismo de Base Comunitária” se dá de forma similar à escolha do tema gentrificação para os debates no Vidigal. O conceito "turismo de base comunitária" nasce na academia, e também é apropriado por atores locais nas favelas que reivindicam o protagonismo dos moradores no turismo.

Segundo Bursztyn et al. (2009), o turismo de base comunitária é uma modalidade do turismo sustentável cujo foco principal é o bem-estar e a geração de benefícios para a comunidade receptora. Nos anos 2000, essa modalidade se expande no Brasil, em especial em comunidades afastadas dos centros urbanos. Um dos mais famosos e bem-sucedidos casos é a experiência citada por Cruz (2009) na Prainha do Canto Verde, comunidade de pescadores artesanais, localizada no município de Beberibe, no Ceará, que enfrentava dificuldades de sobrevivência apenas com a pesca artesanal e a pressão de agentes imobiliários. Em 1992, um executivo suíço, René Schärer, envolve-se com a comunidade e decide prepará-la "para o desenvolvimento de um turismo com base comunitária. A partir do uso de técnicas de planejamento participativo, a comunidade é estimulada a pensar criticamente o uso de seu território e o desenvolvimento do turismo" (CRUZ, 2009, p. 107). 
A autora indica que a comunidade conseguiu impedir a entrada de especuladores imobiliários, e a pesca continuou sendo a principal atividade econômica; o turismo tornou-se uma atividade complementar que gera renda para dinamizar a economia local e fortalecer os laços sociais. A comunidade conseguiu assumir um papel central no turismo local, e tal papel foi conquistado com a organização da comunidade na resistência à uma "invasão iminente" ou a um "impacto prejudicial” à comunidade (CRUZ, 2009, p.108). Trago este caso, pois esse cenário se assemelha ao cenário em debate no Congresso na Rocinha, que traz o tema turismo de base comunitária para o contexto urbano das favelas.

A primeira mesa do evento tratou do tema Turismo e Comunidades e contou com a presença dos palestrantes Jorge Luiz Barbosa, que apresentou um breve histórico das Favelas no Rio de Janeiro, e Rafael Fortunato, que apresentou seu projeto de extensão Rede Brasilidade Solidária e sua atuação no Morro do Borel na Zona Norte do Rio. O pesquisador explicou que o Borel foi uma das primeiras favelas do Rio e a primeira a ter uma associação de moradores. Nos encontros na favela para filmagem do vídeo Borel tour: tradição e vivências num morro carioca (2014) os moradores apontaram que a ideia é garantir com o turismo que essa história não seja esquecida.

Em seguida foi exibido o documentário Em Busca de Um Lugar Comum (2012). Tomando por base as pesquisas realizadas por Bianca Freire-Medeiros na Rocinha, o documentário nos leva em diferentes roteiros, realizados por diversas agências e guias na favela, com especial enfoque nos discursos dos guias e nas respostas dos turistas.

Na parte da tarde foi organizada uma mesa com professores e pesquisadores da área do turismo, da qual fiz parte junto com Teresa Mendonça e Cleber Castro. Mendonça abriu a mesa falando do Turismo de Base Comunitária e sua importância no empoderamento das comunidades locais, em especial sobre a possibilidade de construção de um próprio "selo", da própria imagem que se quer pôr em circulação no turismo. Castro falou da experiência de cartografia social ${ }^{7}$ da UERJ, parte do projeto de extensão Rede Brasilidade Solidária no município de Teresópolis (RJ), e a experiência com os mapeamentos participativos visando a produção de novas territorialidades associadas ao turismo. E eu abordei os novos roteiros de turismo de base comunitária em favelas cariocas, destacando como as favelas estão come-

7 As cartografias sociais são uma modalidade de cartografia em que as próprias comunidades e agentes sociais constroem os mapeamentos, com base em suas interpretações e percepções (CAstro \& Fortunato, 2014). 
çando a se especializar, explorando as suas particularidades e elaborando novos produtos, como por exemplo o ecoturismo em favelas.

No segundo dia de evento, a primeira mesa reuniu o jornalista André Balocco, idealizador do Guia das Comunidades ${ }^{8}$ do Jornal O Dia, empreendedores e guias locais de algumas favelas. A primeira a falar foi a representante do Santa Marta, que recupera como o turismo nesta favela foi promovido e incentivado pelo Governo do Estado. De acordo com Freire-Medeiros, Vilarouca e Menezes (2012), esta favela surge como atração turística a partir de uma política pública em parceria entre os governos federal, estadual e municipal no projeto Rio Top Tour, inaugurado no Santa Marta em 2010. Este projeto nasce com objetivo de criar roteiros turísticos em favelas onde há UPP instaladas, estimulando a visitação turística. Segundo Barbosa (2015), atores externos também se interessaram por essa nova fronteira aberta no mercado turístico de favelas. Agências de turismo já especializadas em passeios turísticos em favelas, com atuação na Rocinha, passaram a atuar também no Santa Marta, e sua forma de guiar turistas foi alvo de críticas entre os moradores, que se organizaram em um Comitê de Turismo do Santa Marta.

Em seguida, a palavra foi passada para o representante do Fórum de Turismo da Rocinha que, junto com o Presidente da Associação de Moradores do Laboriaux e o representante da ONG Favela Verde, falam do projeto de Ecoturismo de Base Comunitária que está sendo elaborado pela Associação de Moradores do Laboriaux em parceria com a ONG Favela Verde.

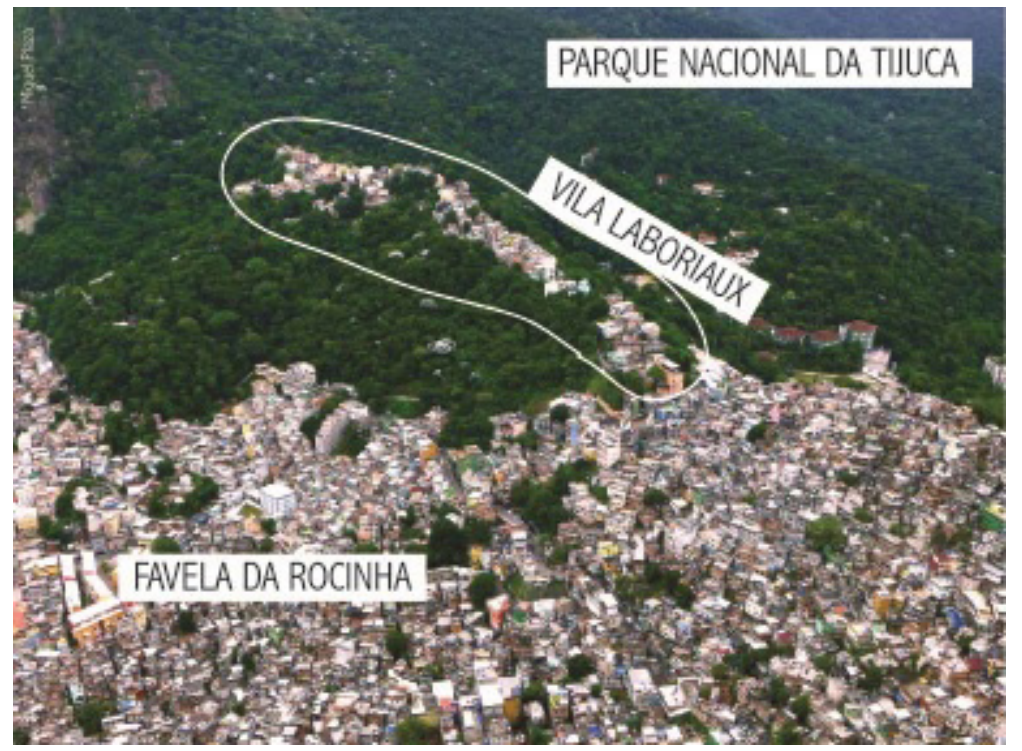

Figura 4. Foto aérea da Rocinha apontando a localização do Laboriaux. Fonte: Acervo de Favela Verde.

8 Caderno especial do Jornal O Dia que traz dicas de para onde ir, o que visitar, onde comer em favelas do Rio de Janeiro. 
O Laboriaux é um dos sub-bairros da Rocinha e está localizado na parte mais alta da favela, em meio à Mata Atlântica do Parque Nacional da Tijuca. Desde 2014, a ONG Favela Verde, atua em parceria com o Associação de Moradores e o PNT buscando "a sustentabilidade urbana das favelas adjacentes a áreas naturais protegidas, visando a convivência entre os sistemas naturais e urbanos" (Favela Verde $^{9}$ ). Desta colaboração nasceu o projeto de Ecoturismo de Base Comunitária, que vem sendo construído e pensado pelos moradores para benefício dos moradores, e em resposta ao turismo comercializado por diversas agências na Rocinha, que segundo os moradores "não deixam nada".

Por fim, o guia local que trabalha com turismo na região da Penha inicia sua fala destacando que o "Rio de Janeiro não vive só para as Olimpíadas ou para Copa do Mundo, porque tudo isso vai passar, o que fica é o legado”. Único representante na mesa da Zona Norte do Rio, nova fronteira de expansão do turismo em favelas, especialmente após a instalação da UPP no Complexo do Alemão, fala sobre o CONTUR, Rede de Conexão de Turismo em Favelas. Fundada em 2014, reúne empreendedores e guias locais de turismo, com o objetivo de união e colaboração entre estes atores, para a expansão do turismo em favelas para além da Zona Sul, e para além das já consagradas favelas turísticas como Rocinha e Santa Marta. Para isso, o grupo se formou com representantes de diversas áreas da cidade. Na presidência do CONTUR à época estava um guia do Complexo do Alemão e na vice-presidência um empreendedor local da Rocinha. Em parceria com o SEBRAE e com a Secretaria de Turismo do Rio de Janeiro, foi organizado o Guia das Comunidades, que apesenta algumas das favelas, os principais atrativos, bares, restaurantes, e guias e condutores para contato nessas áreas. Esta mesa apresentou e representou a expansão do turismo em favelas, suas novas articulações e redes formadas em torno desse turismo no CONTUR, além de apresentar uma preocupação com o legado do turismo nesses territórios.

É importante explicar que, quando se fala de legado, convencionou-se que se trata de algo que se deixa para alguém e para o futuro, no caso das favelas, o que fica do turismo em favelas para os moradores e para o território. O termo legado populariza-se ainda nos documentos oficiais, em especial no Dossiê de candidatura do Rio de Janeiro à cidade-sede dos Jogos Olímpicos de 2016 (2009), onde o legado dos jogos é um elemento central da proposta que reúne o Parque Olímpico, a revitalização da Zona Portuária, melhorias na mobilidade urbana da cidade, melhorias na segurança pública, além de inserção social.

9 Ver: http://www.favelaverde.net/. Acesso em: 19 de outubro de 2016. 
No livro Legados de Mega-Eventos Esportivos (2008), Lamartine da Costa et al. acreditam que foram construídos e reunidos novos significados para os legados de megaeventos que transitam "entre sonhos e realidades, projetos estruturantes necessários, projetos utópicos, limites, diferenças, convergências, contradições, experiências diversas ocorridas em vários países”. Os organizadores concordam ainda que megaeventos esportivos estruturam possibilidades para uma cidade, são importantes catalisadores de melhorias da qualidade de vida e podem auxiliar no processo de regeneração de uma cidade nas áreas de habitação, transporte, segurança, educação, entre outras (MINISTÉRIO DO ESPORTE, 2008).

Nas falas dessa manhã foi possível observar como os empreendedores das favelas estão se apropriando do discurso sobre legado no contexto dos megaeventos, e na parte da tarde, na mesa com representantes do poder público, veremos como o debate da manhã preparou os ânimos e os discursos para cobrar ações do Estado nas favelas, especialmente quando se trata do turismo. Mediada pelo assessor especial da presidência do Instituto Pereira Passos (IPP), com participação de representantes da Secretaria Estadual e Municipal de Turismo do Rio de Janeiro, a mesa abriu defendendo a importância das favelas para o Rio de Janeiro. O mediador argumentou que há favelas em várias cidades do mundo, mas no Rio de Janeiro, essas assumem uma configuração de grande relevância, não só pela sua grandeza, mas pela importância política, social e cultural na conformação da cidade, da sua cultura, e da maneira de ser do carioca.

Passada a palavra para Claudio Poty, representante da Secretaria Estadual, este inicia explicando que veio ao congresso para demonstrar o apoio da Secretaria ao "turismo em comunidade" e entender as demandas e o foco deste movimento. Sobre turismo comunitário, explica que é uma tendência mundial que demanda planejamento e este deve vir dos moradores da favela para a secretaria. Explicou que o CADASTUR, cadastro de profissionais de turismo no MTur, é realizado na Secretaria Estadual e destacou que os albergues, bares e restaurantes são nichos interessantes a serem desenvolvidos nas comunidades, e que se cadastrados terão acesso a divulgação e incentivos. Por fim, falou da Agência Estadual de Fomento (AGERIO), que já deu financiamento para abertura de cama e café em favelas, um nicho que considera importante e necessário para as Olimpíadas. Para concluir, Claudio fala da necessidade de quartos para as olimpíadas, e afirma que "os turistas vão querer conhecer as comunidades", e completa "o safari não foi legal, mas aconteceu, já passou o momento deste tipo de turismo, agora é a hora de vocês se unirem para o turismo passar a ser feito por vocês". 
Em seguida, Philipe Campello, representante da Secretaria Municipal de Turismo, inicia sua fala apresentando o site do Centro de Pesquisa e Estudos do Turismo ${ }^{10}$ para divulgar a situação do turismo na cidade. Campello recupera também o surgimento do turismo em favelas durante a Eco 92, e explica que “para não usar safari, falará em turismo contemplativo que é menos agressivo". E explica a importância de se avançar deste modelo de turismo contemplativo para o turismo de experiência, e que os primeiros passos para isso já foram dados com a parceria com o SEBRAE, que faz os diagnósticos e identifica novos produtos nas favelas, "coloca um novo outro produto na prateleira". E reforçou que a intenção é trabalhar na promoção dos “produtos certos", e que quem vai definir estes produtos são os moradores, como foi feito na publicação do Guia das Comunidades. Philipe encerra sua fala colocando a Secretaria à disposição e defendeu que "o Rio só é Rio porque na nossa história tem uma coisa chamada comunidade”.

Encerradas as falas da mesa, o mediador abriu para as perguntas e foi neste momento que se deu um dos mais importantes debates do Congresso. Empreendedores e guias locais fizeram várias colocações, sobretudo a respeito das pesquisas e dados coletados nas favelas, que, segundo eles, não retornam para os moradores. Reforçaram, ainda, a necessidade de a gestão do turismo em favelas ser feita de forma participativa, envolvendo a população local. Os empreendedores e guias destacaram que tentaram discutir os impactos negativos em âmbito local, em espaços como o Fórum de Turismo da Rocinha e o Comitê de Turismo do Santa Marta, mas que não houve um acompanhamento destes impactos pelo governo que tem sido um dos principias estimuladores do turismo nas favelas. E explicam que eles (moradores) conviviam com os turistas levados por agente externos que não respeitavam os moradores, as histórias e as memórias das favelas.

A colocação sobre pesquisadores e guias externos traz um aspecto comum: pessoas de fora que se aproveitam, ou "exploram" a favela, seja acadêmica ou financeiramente, sem deixar "um legado" para os moradores. Além disso, os moradores se sentem excluídos dos processos decisórios, em especial sobre as políticas públicas implementadas sem debates locais. A fala de uma empreendedora local resume bem este sentimento: “estou cansada de ser objeto. Eu sou protagonista!". Por fim, o grupo na plateia demandou um setor nas Secretarias Estadual e Municipal de Turismo voltado para território de favela e com financiamento público para os projetos de inclusão.

10 Ver: http://www.favelaverde.net/. Acesso em: 19 de outubro de 2016. 


\section{GRUPO DE TRABALHO SOBRE TURISMO EM FAVELAS NA CÂMARA DOS VEREADORES DO RIO DE JANEIRO}

Logo após o I Congresso de Turismo de Base Comunitária na Rocinha, foi noticiado em um jornal do Rio de Janeiro que um projeto de lei estava em tramitação na Câmara de Vereadores visando a "proibição de realização de quaisquer formas de turismo degradantes nas comunidades carentes da cidade do Rio de Janeiro" (LUPARELLI, 2015a). A notícia repercutiu entre os guias locais das favelas e na mídia. A rádio CBN organizou então um debate ${ }^{11}$ entre o vereador, autor do projeto, e um guia local do Santa Marta. Ao final do debate, o guia convidou o vereador para uma visita a favela.

Segundo relato do Vereador, na visita ao Santa Marta, ele percebeu que nem todos os passeios nas favelas exploram a pobreza e os moradores, em especial, as visitas organizadas pelos guias locais. O vereador convidou então os guias locais de Santa Marta para uma reunião na Câmara Municipal e expandiu o convite para outros guias locais de outras favelas. O convite chegou até mim por conta da minha participação no Congresso da Rocinha.

Em maio de 2015, aconteceu a reunião ampliada com o Vereador em que estiveram presentes guias do Alemão, Tabajaras, Cabritos, Santa Marta, São Carlos, Vidigal, além de pesquisadores, representantes de ONGs e agente do Rio + Social. No início da reunião, o vereador apresentou seus assessores, compôs a mesa com representantes da Secretaria de Turismo e distribuiu o texto impresso do projeto de lei que, segundo ele, não chegou a ser protocolado. Em seguida, exibiu o vídeo "Pobre"12, da Produtora Porta dos Fundos, que ironiza o turismo em favelas.

O vereador explicou que nunca teve a intenção de proibir o turismo na favela, mas sim “a espetacularização da pobreza”. A palavra passou então para o subsecretário especial de turismo, que falou do trabalho da prefeitura junto aos empreendedores e, em parceria com o SEBRAE para desenvolver e divulgar novos produtos nessas áreas, que um dos resultados desta parceria foi publicação do Guia das Comunidades e o Guia de Albergues, que incluiu também os de favela. "O turismo em favelas tem tudo para dar certo", argumentou, desde que sejam discutidos seus benefícios e os prejuízos, e as decisões sejam subsidiadas por um levantamento técnico.

O vereador propõe, então, montar um grupo de trabalho para construir um novo projeto de lei que beneficie os guias locais e passa a palavra para a plenária.

11 Ver: http://www.clipnaweb.com.br/clipping/conteudo_v2.asp?reg=405751\&midia=rd\&empres $\mathrm{a}=$ camara\&pala vra=Celio\%20Lupparelli. Acesso em: 19 de outubro de 2016.

12 Ver: https://www.youtube.com/watch?v=8NlLQp2xmZ8. Acesso em: 19 de outubro de 2016. 
Segue-se uma série de falas sobre o turismo em favelas, com sugestões para os debates no grupo de trabalho e possíveis alterações no projeto de lei. No processo, o CONTUR reforça seu papel de rede que articula e conecta os profissionais locais do turismo em favelas com seus principais colaboradores, entre os quais ganhou destaque o SEBRAE.

O grupo apontou que o foco central deveria ser a defesa do turismo como elemento de inclusão social, e, para isso, seria preciso debater o fomento aos comércios locais; melhorias de transporte nas favelas e para as favelas; a segurança pública; o turismo noturno; as dificuldades para organizar festas e eventos; a conscientização e estabelecimento de parcerias entre agências/operadoras e guias locais para realização de "um turismo consciente, eficiente e gerador de renda para a favela”. Defenderam, ainda, uma maior participação dos representantes do turismo em favelas em eventos oficiais, para que possam divulgar seus trabalhos e estabelecer as parcerias necessárias ao desenvolvimento da atividade. Encerrada a reunião, ficou-se de instituir o grupo de trabalho e marcar a próxima reunião.

Na reunião de junho, estavam presentes a equipe do vereador, representantes de diversas favelas e da Secretaria Municipal de Turismo, que levou duas leis a serem consideradas: a Portaria $\mathrm{N}^{\circ} 27$, de 30 janeiro de 2014, que regulamenta a profissão de guia, e a Lei Geral do Turismo ${ }^{0}$ 11.771/o8, que dispõe sobre a Política Nacional de Turismo, define as atribuições do Governo Federal no planejamento, desenvolvimento e estímulo ao setor turístico. Os principais apontamentos foram sobre a profissão e atuação do guia de turismo, destacando que nas legislações aparecem as figuras de monitor e condutor, que em áreas delimitadas podem atuar sem ter registro profissional.

Este ponto gerou um caloroso debate. Para os guias locais, a possibilidade de monitor ou condutor em zona delimitada é interessante. Primeiro porque, em vários dos registros de negócios nas favelas, os comércios ou empreendedores estão categorizados em Área de Especial Interesse Social (AEIS). Segundo porque defender o "condutor em área delimitada" significa abrir a possibilidade de o morador atuar enquanto está se formando para ser guia.

Por outro lado, o representante da Secretaria de Turismo e a agente do Rio + Social apontaram seus receios com o uso dessa classificação para autorizar os condutores. Para o representante da Secretaria de Turismo, esta regulamentação afastaria a favela do mercado e das grandes operadoras, o que poderia ser ruim em uma baixa temporada, quando as grandes operadoras teriam condições materiais de manter um fluxo de turistas para as favelas. Já para a agente do Rio + Social, o uso da categoria "de especial interesse social” poderia reforçar a segregação quando 
o que se deseja é integrar a favela à cidade. Ambos destacam que os representantes ali presentes "têm que resolver se querem ser cidade ou Área de Especial Interesse Social”. O represente da Secretaria de Turismo ponderou se uma ideia não seria um projeto similar ao Rio Top Tour, implementado em 2010 no Santa Marta, cujo objetivo era incentivar o turismo em favelas pacificadas.

Vale refletir em torno do debate sobre o uso ou não da categoria Área de Especial Interesse Social (AEIS), criada em 1987 com a promulgação do Plano de Regularização de Áreas de Especial Interesse Social (AEIS). Tal plano permite a atuação de forma mais efetiva e integrada sobre os chamados espaços informais, e funciona como medida para a regularização dessas áreas nas esferas urbanística e administrativa, bem como para garantir a disponibilização dessas áreas para fins habitacionais destinados a população de baixa renda (IPEA/INFUrb, 1998 apud Grostein, 2001).

No Plano Diretor ${ }^{13}$ em vigor na cidade do Rio de Janeiro, encontramos a categoria Área de Especial Interesse permanentes ou transitórias. Estas áreas são

espaços da cidade perfeitamente delimitados sobrepostos em uma ou mais Zonas ou Subzonas, que serão submetidos a regime urbanístico específico, relativo a implementação de políticas públicas de desenvolvimento urbano e formas de controle (Prefeitura do Rio DE JANeiro, 2011, p.32).

As Áreas de Especial Interesse podem ser ainda de Interesse Urbanístico (AEIU), quando "destinadas a projetos específicos de estruturação ou reestruturação, renovação e revitalização urbana”; ou Área de Especial Interesse Social (AEIS) aquela destinada a Programas Habitacionais de Interesse Social,

destinados prioritariamente a famílias de renda igual ou inferior a seis salários mínimos, de promoção pública ou a ela vinculada, admitindo-se usos de caráter local complementares ao residencial, tais como comércio, equipamentos comunitários de educação e saúde e áreas de esporte e lazer (PREfEitura Do Rio DE JANEIRO, 2011, p.32).

As Áreas de Especial Interesse Social por sua vez se dividem em:

13 “[...] instrumento legal que propõe uma política de desenvolvimento urbano e orienta o processo de planejamento do Município” (PREFEITURA Do Rio DE JANEIRO, 2011, p.32). Disponível em: http:// www.rio.rj.gov.br/web/smu/exibeconteudo?id=2879239. Acesso em: 19 de outubro de 2016. 
a) AEIS 1, caracterizada por: 1. áreas ocupadas por favelas e loteamentos irregulares; 2. conjuntos habitacionais de promoção pública de interesse social e em estado de degradação; b)AEIS 2, caracterizada por: 1. imóveis não edificados, não utilizados e subutilizados em áreas infraestruturadas; III. área de Especial Interesse Ambiental - AEIA é aquela destinada à criação de Unidade de Conservação ou à Área de Proteção do Ambiente Cultural, visando à proteção do meio ambiente natural e cultural; IV. área de Especial Interesse Turístico - AEIT é aquela com potencial turístico e para qual se façam necessários controle de usos e atividades, investimentos e intervenções visando ao desenvolvimento da atividade turística; V. área de Especial Interesse Funcional - AEIF é aquela caracterizada por atividades de prestação de serviços e de interesse público que exija regime urbanístico específico; VI. área de Especial Interesse Agrícola - AEIG é aquela destinada à manutenção da atividade agropecuária, podendo abranger as áreas com vocação agrícola e outras impróprias à urbanização ou necessárias à manutenção do equilíbrio ambiental, recuperáveis para o uso agrícola; VII. área de Especial Interesse Cultural - AEIC é aquela destinada a afetação dos Sítios Culturais, definidos no art. 140 desta Lei Complementar, por conservar referências ao modo de vida e cultura carioca, necessária à reprodução e perpetuação dessas manifestações culturais (Prefeitura do Rio de JANeiro, 2011, p. 32-33).

As duas últimas reuniões começaram a se encaminhar para a elaboração de um novo projeto de lei que propõe a criação da modalidade turística denominada Turismo em Favelas, definida para efeitos do projeto de lei como a realização de visitas guiadas aos ativos turísticos das favelas cariocas (LUPARELLI, 2015). O projeto classifica as favelas onde há atividades turísticas como Áreas de Especial Interesse Turístico (AEIT) e inclui essas áreas no planejamento turístico oficial da cidade do Rio de Janeiro. A intenção seria garantir um planejamento participativo com os profissionais das cadeias produtivas locais, guias locais, a Rede de Conexão de Turismo em Favelas (CONTUR), os fóruns de turismo locais e a Comissão Permanente de Turismo da Câmara Municipal do Rio de Janeiro. Dentre as ações de planejamento turístico nas favelas foram citadas na lei:

I - criação de roteiros históricos, culturais, gastronômicos e ecológicos, reunindo os principais ativos turísticos locais;

II - ampliação da divulgação nacional e internacional do Turismo em Favelas através da Secretaria Especial de Turismo e da Riotur; 
III - fomento a atividades de educação ambiental e de valorização histórica e cultural locais;

IV - realização de diagnóstico aprofundado dos serviços, recursos e atrativos turísticos das localidades e disponibilização em meio digital e impresso através das publicações do Rio Guia Oficial;

V - promoção da capacitação dos agentes de informações da Cidade em relação ao segmento e workshops para o mercado operador turístico;

VI - promover parcerias entre agências e operadoras de turismo e os guias locais que realizam o turismo de base comunitária;

VII - criação de fórum permanente de pesquisa sobre Turismo em Favelas, com a participação de departamentos de instituições de pesquisas voltadas para o estudo das favelas cariocas;

VIII - criação da semana de comemoração do Turismo em Favelas, a ser realizada na semana do dia 29 de maio, tornando-se este o dia do Turismo em Favelas, constando do Calendário Oficial de Eventos da Cidade do Rio de Janeiro, com fomento a atividades comemorativas e promotoras da modalidade (LUPARELLI, 2015b, p.1).

Por fim, o projeto de lei destaca que a Secretaria Especial de Turismo e a Riotur "criarão instrumentos de estímulo à realização de turismo de base comunitária" (LupARELli, 2015b, p.3), o que atende as demandas do CONTUR e de representantes do turismo em favelas, conforme apresentado nos debates do I Congresso de Turismo de Base Comunitária da Rocinha.

O Projeto de Lei ainda se encontra em tramitação na Câmara dos Vereadores e, se aprovado, se somará a outras duas leis que já abordaram o tema turismo em favelas. A primeira, como vimos, foi a Lei Municipal $n^{0} 4.405 / 2006$, de autoria da Vereadora Lilian Sá, que "dispõe sobre a inclusão do Bairro da Rocinha no Guia Oficial e no Roteiro Turístico e Cultural do Município do Rio de Janeiro"; e a segunda, a Lei Municipal no 5·310/2011, de autoria do Vereador Jorginho da SOS, que "dispõe sobre a inclusão do Complexo do Alemão no Guia Oficial e no Roteiro Turístico e Cultural do Município do Rio de Janeiro”.

Diferente das leis citadas anteriormente, que focam uma na Rocinha e outra no Complexo do Alemão, o projeto de Luparelli cita um ampliado grupo de favelas turísticas, o que demostra um reconhecimento da expansão da atividade. É importante destacar que o grupo de trabalho mobilizou cerca de 20 representantes de diversas favelas da cidade, entre elas, Rocinha, primeiro caso no Rio desde 1992; Prazeres; Pereira da Silva; Tavares Bastos; Babilônia e Chapéu Mangueira, que 
representaram a primeira fronteira de expansão do turismo em favelas entre 2000 e 2008; Pavão, Pavãozinho e Cantagalo; Santa Marta; Complexo do Alemão; Complexo da Penha; Vidigal; Tabajaras e Cabritos; Borel; Formiga; Salgueiro; Turano; Mangueira; São Carlos e Vila Kennedy, que completaram a segunda fronteira de expansão do turismo em favelas desde 2009 até os dias de hoje, já no contexto dos megaeventos.

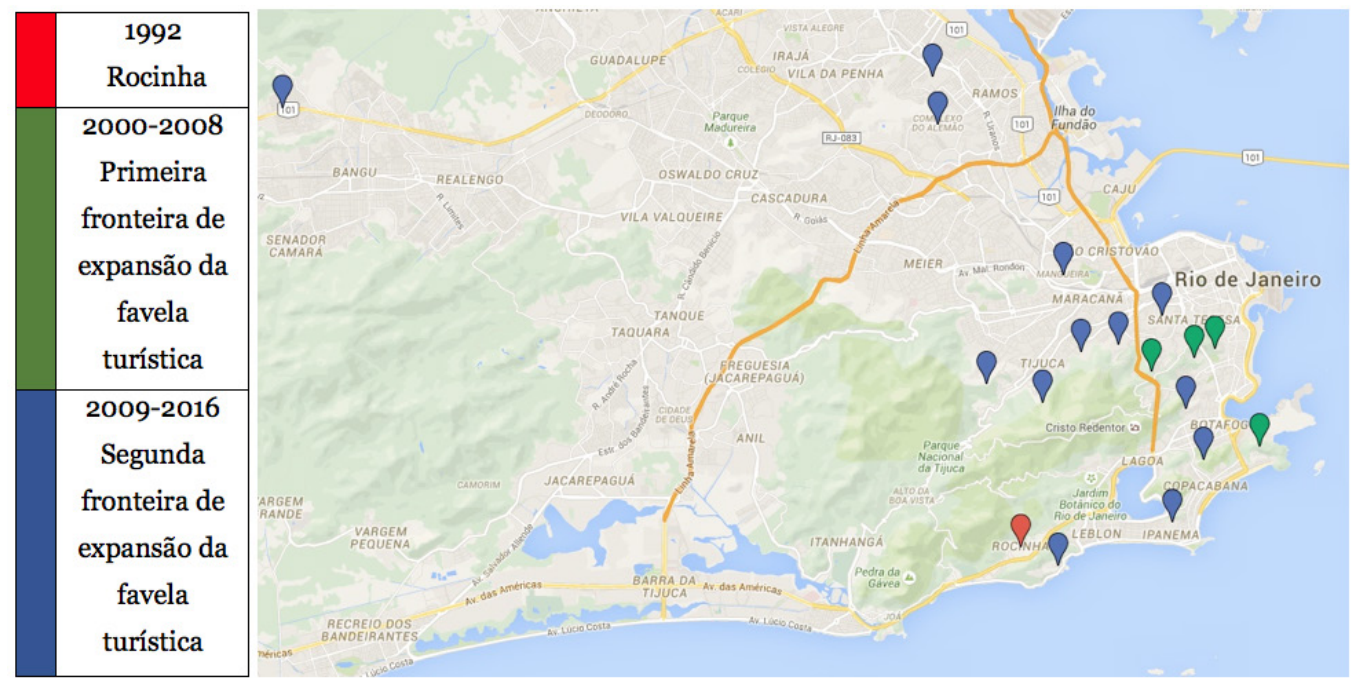

Figura 5. Mapa da expansão das fronteiras do turismo em favela. Fonte: Mapa da Autora

Ao longo dos debates, foi possível, portanto, acompanhar o crescimento e amadurecimento do CONTUR em termos de organização interna e externa, bem como compreender também a expansão das novas fronteiras do turismo em favelas.

\section{CONSIDERAÇ̃̃ES FINAIS}

O turismo em favelas se expandiu nos últimos anos, como também se ampliaram os espaços para reflexão sobre este fenômeno na favela e fora dessas, como vimos nos debates realizados no Vidigal, na Rocinha e na Câmara dos Vereadores. Ao longo desses debates uma série de temas podem ser destacados para reflexão como, por exemplo, o papel ativo de pesquisadores em campo nas favelas, a exemplo dos pesquisadores que mobilizaram o debate Fala Vidigal!, ou eu mesma como palestrante em um dos debates apresentados; ou ainda o debate sobre empreendedorismo e turismo em favelas, temas estes que ainda merecem atenção em futuras publicações. Nesse artigo, no entanto, optei por focalizar os moradores, bem como os seus discursos sobre turismo nas favelas em diferentes debates e contextos. Para isso é importante localizarmos e refletirmos sobre o momento histórico e a espacialidade de cada um dos eventos aqui relatados. 
Os debates no Vidigal foram realizados na rua, ou melhor, na praça localizada na entrada do Vidigal, ainda no primeiro semestre de 2014, pouco tempo após as chamadas "Jornadas de Junho" de 2013, quando as ruas foram tomadas por manifestações marcadas pela contestação aos megaeventos (HARVEY ET AL., 2013). Neste sentido, a série de debates não estava alheia aos acontecimentos e movimentos de contestação na cidade, no Brasil e no mundo.

Já o Congresso realizado no início de 2015 saiu da praça e foi para a Biblioteca Parque na Rocinha, um espaço do Governo do Estado. Ali se deu um evento mais institucional, organizado por um coletivo local (Fórum de Turismo da Rocinha), agentes governamentais (Rio + Social) e empresariais (SEBRAE). É importante destacar que, diferente da série de debates no Vidigal, apesar de realizado em um espaço público, o congresso não atraiu moradores da favela: os poucos que participaram eram todos empreendedores locais na área do turismo. Além disso, o congresso foi também marcado pela reflexão e problematização, olhando o passado do que foi a Copa da FIFA no Brasil para planejar um futuro para além das Olimpíadas de 2016.

O Grupo de Trabalho sobre Turismo em Favelas na Câmara de Vereadores se apresentou como um encaminhamento final do Congresso da Rocinha. Isso porque os mesmos atores presentes no congresso se reuniram ao longo do GT na Câmara para a elaboração de um novo projeto de lei sobre turismo em favelas.

Em Futuro Passado (2006), o historiador Reinhart Koselleck nos traz uma importante contribuição para pensar diferenças cruciais entre os debates em tela. Para Koselleck, passado, presente e futuro podem se alterar de acordo com o grupo social e época em questão, modificando-se, assim, o modo como são percebidos e projetados, bem como as relações entre eles. Para isso, o historiador elabora dois conceitos: "espaço de experiência" e "horizonte de expectativas". A experiência seria o passado diretamente vinculado ao presente, aquele em que os acontecimentos são lembrados, ou as experiências coletivas, que são transmitidas através de gerações e/ou instituições. Já as expectativas estão relacionadas ao futuro e correspondem a um universo de antecipações, ou seja, é tudo aquilo que em um determinado presente se vislumbra como possibilidade de futuro. Assim, tanto o passado como o futuro são relativos a um presente e a um grupo social, as experiências no passado variam de acordo com o grupo social e de acordo com o presente em questão, assim como o futuro e as expectativas em relação a estes também vão variar de acordo com presente e o grupo social (KosELLECK, 2006, p.308-310). John Urry, em seu livro What is the Future? (2016), elabora seis métodos de antecipação de futuros: podemos antecipar futuros a partir do aprendizado com o 
passado pessoal e coletivo; através de estudos sobre futuros que falharam; através das distopias, utopias, extrapolações e ainda da construção de cenários. Para Urry, decorreria daí a possibilidade de vislumbrar três tipos de futuros: o provável, o possível e o preferível. As reflexões de Koselleck e Urry trazem criativas formas de análise e comparação entre os debates no Vidigal em 2014 e na Rocinha e na Câmara dos Vereadores no ano seguinte.

No Vidigal de 2014 era possível identificar um "espaço de experiência" relacionado às lutas do Vidigal contra a remoção nos anos 1970, assim como o conhecimento sobre outros processos de gentrificação divulgados pelos pesquisadores, além dos já mencionados movimentos nas ruas em 2013 e 2014. Diante disso, os debates se deram com muitos discursos inflamados de grupos organizados e preocupados com o futuro da favela, que naquele momento tinham um "horizonte de expectativa" elaborado com base não apenas no espaço de experiência citado, mas também na informação sobre os processos de gentrificação e a observação empírica das transformações na paisagem arquitetônica e social da favela, com novos albergues surgindo, novos moradores e novos investidores chegando a cada semana. Apesar de este não ser o futuro preferível, era visto pelos moradores como o futuro provável a ser combatido e debatido com toda a força.

Já em 2015, nos debates na Rocinha e na Câmara dos Vereadores, temos um espaço de experiência e um horizonte de expectativas bastante diferentes daqueles presentes no Vidigal. Para o grupo de empreendedores e guias locais, o que aparece como possibilidade de futuro nos debates são "os legados", que passam a ser acionados para cobrar as promessas do Estado, que se engajou na mobilização da expansão das fronteiras da favela turística. Não surpreende, assim, a ausência do tema gentrificação. Como dito no início deste artigo, meu objetivo aqui não foi apresentar as polarizações em torno do tema turismo em favelas. Os atores sociais envolvidos estão todos problematizando e refletindo sobre turismo de acordo com suas experiências pessoais e ou coletivas. Passados, presentes e futuros são elaborados e projetados com base na realidade de cada grupo social. $\mathrm{O}$ fundamental é perceber que os moradores das favelas estão debatendo e respondendo a este fenômeno, se apropriando das linguagens com as quais se identificam de acordo com seu "espaço de experiência" e "universo de expectativa". Como já dizia Freire-Medeiros:

Favelado, guia, gringo não são apenas identidades que os atores sociais trazem para a favela turística, mas identidades que são construídas por meio da favela turística. Essas identidades são construídas, observadas e julgadas, não apenas 
exibidas. Todos têm uma opinião sobre as atitudes dos demais, ainda que sejam opiniões contraditórias e baseadas em suposições (FrEIRE-MedeIros, 2009, p. 150, grifos meus).

No Vidigal, os debates atraíram basicamente dois grupos de moradores; o primeiro, formado pelos "antigos" moradores, oriundos de famílias que já estão no Vidigal há muitos anos, que também podem ser chamados de "nascidos e criados", pois nasceram e foram criados no Vidigal. Este grupo se divide em dois subgrupos que denomino aqui de "não-organizados" em ONGs, coletivos ou associação de moradores; o subgrupo dos "organizados", que reúne os moradores organizados em ONGs, coletivos ou associações, e que, neste caso, não falam apenas por si só, mas também em nome desses grupos que representam; e o segundo grupo, composto pelos novos moradores de classe média, brasileiros ou estrangeiros. Esses dois grupos foram recorrentes na plateia de todos os debates, como falas muito marcadas por estas novas relações de identidade no Vidigal.

Já o Congresso na Rocinha e o GT na Câmara dos Vereadores atraíram os empreendedores e guias locais; e assim como no Vidigal, nestes espaços foi possível notar outra produção de identidades a partir da favela turística, a de empreendedores e guias locais e a de empreendedores e guias de fora. Ao fim ao cabo, como diria nosso guia local da Penha, o que está por trás de todo este debate sempre é o morador, que morador é este e que posição ele ocupa é sempre uma questão central. Novos e antigos moradores, organizados ou não organizados em coletivos ou associações, empreendedores e guias locais, todos têm feito o exercício de problematizar sobre o turismo, e tanto o debate sobre gentrificação quanto sobre turismo de base comunitária foram organizados porque a favela turística estava sendo interpretada e questionada, porque relações de identidade estavam sendo formuladas e reformuladas.

$\mathrm{E}$, assim como a favela turística define ou redefine novas identidades nas favelas, novas sintaxes, gramáticas e vocabulários serão acionados na reelaboração dessas identidades. Os moradores, em especial aqueles organizados em coletivos, estão afiados em relação aos vocabulários acionados e como estes são capazes de traduzir processos e demandas identificados pelos moradores. Como vimos, no caso da apropriação do vocabulário sobre gentrificação, que respalda a concepção de novos e antigos moradores, assim como o turismo de base comunitária respalda a elaboração da figura do guia de fora e do guia local, da grande operadora do turismo de massa, e da operadora local do turismo de experiência. Assim como, no contexto dos megaeventos, coletivos organizados se apropriaram 
do vocabulário do Estado, como por exemplo, o termo legado, presente em todas as narrativas oficiais de megaeventos, e usam o termo para questionar e cobrar as ações prometidas pelo Estado nas favelas.

Por fim, os eventos analisados mostram como diferentes grupos são mobilizados por diferentes temáticas que movimentaram as favelas entre 2014 e 2015, acionando redes e camadas de debates distintas, porém todas capazes de mobilizar e movimentar a favela. Estes debates movimentaram pessoas pelas favelas e movimentaram favelas que até então não estavam tão mobilizadas pelo turismo ou questões correlatas.

Em última análise, os debates mostram como o turismo na favela se apresenta como objeto de interesse público. Conforme previsto por Jafar Jafari (2005), o turismo passa a ser percebido, ao menos nas favelas, como um poderoso fenômeno sociopolítico, investigado e interpretado por uma série de atores sociais, entre eles, acadêmicos, comunidades, gestores públicos, empreendedores e movimentos sociais organizados, interessados em compreender seus efeitos, seus limites e refletir sobre o futuro da atividade.

\section{REFERÊNCIAS BIBLIOGRÁFICAS}

Barbosa, Gabriel Ferreira. A Favela Santa Marta e seus guias de turismo: identidade, mobilização e conflito. Revista Iberoamericana de Turismo, v. 5, p. 169-179, 2015.

Bataller, Maria Alba Sargatal. O estudo da gentrificação. Revista Continentes (UFRRJ), ano 1, n. 1, p. 09-37, 2012.

BERESFord, Mike. "Que tal uma trilha no Vidigal? Passeio oferece visão alternativa da cidade dos Jogos Olímpicos”. Disponível em: https://www.rio2016.com/noticias/ que-tal-uma-trilha-no-vidigal-passaporte-verde-leva-turistas-a-comunidade. Acesso em: 19 de outubro de 2015 .

Bartholo, Roberto; Bursztyn, Ivan; Delamaro, Maurício César. "Turismo para quem? Sobre caminhos de desenvolvimento e alternativas para o turismo no Brasil”. In: Bartholo, Roberto; Bursztyn, Ivan; Sansolo, Davis Gruber (Org.). Turismo de Base Comunitária: Diversidade de Olhares e Experiências Brasileiras. 1ed. Rio de Janeiro: Letra e Imagem, v. 1, 2009 p. 76-91."

CASTRO, Cleber; Fortunato, Rafael. Redes populares de turismo e mapeamento participativo: o caso da Rede Brasilidade Solidária em Teresópolis-RJ. Revista Continente, v. 5, p. 150-161, 2014.

Coutinho, Marina Henriques. O uso da abordagem dialógica do teatro em comunidades na experiência do grupo Nós do Morro, da favela do Vidigal, no Rio de Janeiro. 
Interações: Cultura e Comunidade (Faculdade Católica de Uberlândia), v. 1, p. 108-124, 2006.

CRuz, Rita de Cássia Ariza. “Turismo, produção do espaço e desenvolvimento desigual: para pensar a realidade brasileira” In: BARTHOLO, Ricardo.; SANSOLO, Davis Gruber; Bursztyn, Ivan. (Org.). Turismo de Base Comunitária: Diversidade de Olhares e Experiências Brasileiras. 1ed. Rio de Janeiro: Letra e Imagem, v. 1, 2009. p. 92-107.

Da Costa, Lamartine et al. (Org.) Legados de Megaeventos Esportivos. Ministérios dos Esportes: Brasília, 2008.

FALA VIDIGAL! Os Moradores Refletem Sobre a Gentrificação. Residents Reflect on Gentrification. Disponível em https://www.youtube.com/watch?v=bdlrpTsIllE. Acessado em 19 de outubro de 2015.

Favela Verde. Disponível em: http://www.favelaverde.net/. Acessado em 19 de outubro de 2015 .

Freire-Medeiros, Bianca. A favela que se vê e que se vende: reflexões e polêmicas em torno de um destino turístico. Revista Brasileira de Ciências Sociais. São Paulo, v. 22, n. 65, p. 61-72, Oct. 2007. Gringo na Laje. Rio de Janeiro: FGV, 2009. . Touring Poverty. Nova Iorque: Routledge, 2013.

Freire-Medeiros, Bianca; Vilarouca, Marcio Grijó; Menezes, Palloma. "Gringos no Santa

Marta: quem são, o que pensam e como avaliam a experiência turística na favela". In: Penalva Santos, Angela; Marafon, Glaucio; Josefina, Maria; Sant’Anna, Gabriel (Org.). Rio de Janeiro: Um território em mutação. Rio de Janeiro: Gramma Livraria e Editora, 2012, v. 1, p. 183-205.

Frenzel, Fabian, Koens, Ko., Steinbrink, Malte, \& Rogerson, Christian M. Slum Tourism State of the Art. Tourism Review International, v. 18 n.2, p. 237-252, 2015.

Grostein, Marta Dora. Metrópole e expansão urbana: a persistência de processos 'insustentáveis'. São Paulo em Perspectiva. v. 15, n. 1, p. 13-19, Jan. 2001.

Harvey, David (et al.) Cidades Rebeldes. São Paulo: Boitempo, 2013.

Jaguaribe, Beatriz; Hetherington, Kevin. "Favela tours: indistinct and mapless representations of the real in Rio de Janeiro". In: SHELler, Mimi, URRY, John. (Org.). Tourism Mobilities. Places to play, places in play. Nova Iorque: Routledge, 2004, p. 155-166.

JAFARI, Jafar. El turismo como disciplina científica: the scientification of tourism. Política y Sociedad, vol. 42, n. 1. p.39-56, 2005.

Koselleck, Reinhart. “'Espaço de experiência' e 'Horizonte de expectativa': duas categorias históricas”. In: KoselLEck, Reinhart. Futuro Passado. Rio de Janeiro: Ed. PUC Rio/ Contratempo, 2006. 
LuPARElli, Celso. Projeto de Lei que dispõe sobre proibição de realização de quaisquer formas de turismo degradantes nas comunidades carentes da cidade do Rio de Janeiro. Câmara dos Vereadores. Rio de Janeiro. 2015a.

Projeto de Lei que cria modalidade turística denominada Turismo em Favelas na Cidade do Rio de Janeiro e dá outras providências. Câmara dos Vereadores. Rio de Janeiro. 2015b.

. Projeto de lei quer proibir visitas guiadas às favelas do Rio. Debate entre o vereador Célio Lupparelli e Thiago Firmino, guia turístico da favela Santa Marta. Disponível em: http://www.clipnaweb.com.br/clipping/conteudo_v2.asp?reg=405 751\&midia=rd\&empresa=camara\&palavra=Celio\%20Lupparelli. Acesso em: 19 de outubro de 2015 .

MacCann, Bryan. Hard Times in the Marvelous City: From Dictatorship to Democracy in the Favelas of Rio de Janeiro. Durham: Duke University Press, 2014.

Peschanski, João Alexandre (et al.). Occupy. São Paulo: Boitempo, Carta Maior, 2012.

Pobre. Porta dos Fundos. Rio de Janeiro, 2014. Disponível em: https://www.youtube.com/ watch?v=8NlLQp2xmZ8. Acesso em: 19 de outubro de 2015.

Prefeitura do Rio de Janeiro. Lei Complementar N.111 de 2011 - Plano Diretor do Município do Rio de Janeiro, aprovado pela Lei Complementar. Rio de Janeiro, 2011.

Plano diretor Disponível em: http://www.rio.rj.gov.br/web/smu/ exibeconteudo?id=2879239 Acessado em 19 de outubro de 2015.

Rio CePetur. Disponível em: http://www.riocepetur.com.br/site/o-cepetur/. Acesso em: 19 de outubro de 2015.

Soares Gonçalves, Rafael. Favelas do Rio de Janeiro: história e direito. Rio de Janeiro: Editora Pallas, 2013.

URRY, John. What is the future? Cambridge: Polity, 2016.

VAN WeEsep, Jan. Gentrification as a research frontier. Progress in Human Geography. Vol. 18, p. 74-83, 1994.

VAsconcelos, Daniel Arthur Lisboa. Turistificação do Espaço e Exclusão Social: a revitalização do bairro de Jaraguá, Maceió-AL, Brasil. Revista Turismo em Análise. São Paulo, v. 16, n.1, p. 47-67, 2005.

Recebido para publicação em: 26/08/2016. Aceito para publicação em: 14/o9/2016. 